\title{
Must the Human Race Really Perish?
}

\author{
Farewell speech held by Prof. Dr. O. JAAG on 14 November 1970 \\ on the occasion of the annual celebration of the Swiss Federal \\ Institute of Technology
}

\begin{abstract}
Apocalyptic end?
'Progress into Chaos', 'Nature in Danger', 'Save the Earth', 'The Devil Will Take You Away Tomorrow', 'World Famine', Our Poisoned Environment', 'Suicide by Installments', 'Suicide or Survival', 'Back to the Stone Age'; these are just a few of the titles that have appeared recently in newspapers and on book covers. Our imperiled environment is being discussed on radio and television programs; it is the object of ominous forecasts and dire warnings that frighten the man on the street. But while some quake at the mere thought of such prophecies they evoke only a condescending smile from others caught up in the euphoria of affluence, who do not believe we will ever experience a rude awakening. After specialists had for decades warned of the deterioration and even destruction of our environment through man himself, the public eye of a sudden focused on these problems. The almost hysterical response brought prophecies of doom and peremptory demands for immediate measures to save mankind.

The duty now devolves on scientists, technicians, administrators and especially environmental engineers to remain alert and obective in the face of new developments, to draw the right conclusions from observations and reflexions and to bend to the task of freeing mankind from the impending danger.

Man first began to match wits with Mother Nature nearly half a million years ago, to impose his will on her and subjugate her in keeping with God's commandment; he was surprisingly successful in this effort.
\end{abstract}

\section{'Subjugate the Earth'}

In prehistorical days the receding or advancing glaciers determined man's choice of habitat, and through his ingenuity he managed to make the best of his existence as a cave-dweller, lake-dweller, hunter, and finally farmer. In time he founded cities that betokened an advanced civilization.

To counter the forces of nature, tidal waves, inundations and landslides he built dams, dikes and other constructions; in his struggle to make optimum use of the water available, man developed sophisticated systems of water supply, canals, locks and aqueducts to serve him for thousands of years. 
Notwithstanding serious mistakes were made: In order to cover his ever-increasing need for wood in the mining, coal and shipbuilding industry, man felled and burnt forests indiscriminantly, creating conditions which could but lead to soil erosion. The soil that had accumulated for centuries was carried to the lowlands, leaving the mountains aride and bare, to form swamps where disease could breed.

The ruinous exploitation of forests was repeated again and again over the centuries in Mesopotamia, along the Eastern Mediterranean, in ancient Greece and Rome, Spain and even on the American Continent, leaving a declining civilization in its wake.

When in Switzerland the forested regions of the Alps were cleared for pastureland such devastation was wreaked that the slopes were left unprotected against avalanches until the exemplary Federal Afforestation Act of 1876 and 1902 put an end to this senseless exploitation.

In setting up his line of defence against the ravages of nature, man has made serious and sometimes irreparable mistakes owing to his shortsightedness, erroneous evaluations and even niggardliness in his choice of means. Since all our crimes against environment seem to have a boomerang effect, the history of mankind is comprised of a continual concatination of catastrophes. Today we have reached a point where the hope of saving the human race from an abyssmal end is getting dimmer and dimmer.

Indeed, the fatal mistakes that were and are still being made have poisoned our environment and made life more and more difficult.

\section{Environmental pollution control : a necessity}

Ever since Presidents Nixon and Johnson launched urgent appeals for environmental pollution control and the Council of Europe proclaimed 1970 'International Conservation Year' the protection of our biosphere has become the most widelydiscussed topic.

It is not that man has overlooked or underestimated the impending danger. All means available have been used in the construction of wastewater treatment plants and incineration facilities for domestic as well as industrial wastes in order to fight the catastrophic consequences of the deterioration of our lakes and rivers. It would be unjust to belittle the progress made in practically all areas of the civilized world in the field of environmental preservation.

\section{Water pollution control}

Switzerland, for instance, can rightly be proud of the fact that approximately half of its population and industry is connected to efficient wastewater treatment plants. The construction of these plants together with an extensive sewerage system cost 5 billion Swiss francs already, and when in 10 to 20 years the first series of measures to protect its waters and environment will have been carried out, the Confederacy will have sacrificed 10 billion Swiss francs for water pollution control. In themeantime, however, much still remains to be done and, admittedly, not all regions tackle the problem with the same amount of zeal or financial resources, facts that have had 
adverse effects especially on those regions dependent on the tourist industry. Yet in view of the rapid growth of the population and expansion of industry more stringent norms must be set for water quality in the interest of water supply, water sports and fisheries. Man's activities are constantly creating new problems and tasks which must be dealt with lest irreparable damage be caused. In addition, it is not sufficient to put one's own house in order, consideration must also be shown for one's neighbors.

\section{Water economy on a long-term basis}

As we do not have unlimited amounts of water, our supplies must be carefully husbanded by circulating it in a closed cycle and reducing the amount of wastewater produced. Commendable progress has been made in this direction in numerous industrial concerns. Notwithstanding, seen as a whole, water consumption is on the increase. Since industrial development and population growth cannot be brought to a standstill, we must make provisions for the time when our water supply will dwindle even further.

A cogent, comprehensive system of water management for the whole of Europe is indispensable. A time will come when water from the Swiss and Austrian Alpine regions will be used to supply the surrounding lowlands and even coastal regions and I can well imagine that water will become a much coveted export article in a not too distant future. This, of course, presupposes that optimum use is made of our water reserves.

At present there must be sufficient water to supply 3.5 billion people with service and drinking water. According to demographic estimates the population of the earth will have increased to 7 billion by the year 2000 and to at least 20 billion by 2100 . Since specific water consumption is constantly on the rise, rainfall alone will no longer suffice to satisfy man's needs. If effective ways to curb the population explosion are not found soon, man must irrigate and settle desert regions which had previously been beyond his reach owing to their aridity. I believe that man will, thanks to his ingenuity, be able to desalinate the ocean's waters to supply urban conurbations and industry and to develop semi-aride and aride regions. Scientific and technological progress as well as world-wide collaboration will be necessary to translate these potentials into reality.

At present, however, we will be fully occupied with preventing the further deterioration of our lakes, rivers and groundwater and the misuse of our waterways through the discharge of solid and liquid wastes. Since there are as yet no bilateral or multilateral agreements governing international waters, such legislation must needs be set up in the interest of the entire European community.

\section{Pollution of our oceans and coastal regions}

In the preservation of our coastal regions and open seas we are faced with some problems and tasks. Our oceans are being polluted by the discharge of bilge and cleaning water, effluents from land and oil pollution from oil tankers. The catastrophes of the 'Torrey Canyon' and 'Pacific Glory' as well as others warn us of what can be expected of such large-scale transportation. 
That the authorities should sanction the storage of nuclear and highly toxic wastes on the ocean floor in containers that are bound to disintegrate in the long-run is, in my opinion, particularly reprehensible. The contamination of the ocean with its fauna and flora is inevitable. It is useless to try to hide from the truth and refer to the high dilutional capacity of the ocean, for a continuous stream of toxic material is discharged into the ocean each and every day.

There it accumulates and is carried to the far-off corners of the earth by the ocean currents. But since the ocean will always be our water reservoir, it is extremely dangerous to tinker with it. Concentrations of toxic elements have already been found in the mussels and fish of the high seas. We cannot afford to minimize these dangers especially since the ocean will, in future, provide a source of nourishment for mankind.

\section{Air pollution}

Parallel to water pollution there has been a steady increase in air pollution by smoke, dust and objectionable and even toxic gases and vapors.

This is a very fateful development for man, animals and plants alike since they are directly dependent on the oxygen in the air. A number of diseases such as irritations and inflammations of the respiratory system, stomach trouble and circulatory disturbances can, in fact, be traced back to air pollution. Weather inversion can havecatastrophic results: the resulting cloak of smog prevents the pollutants from rising into the higher layers of the atmosphere. The consequence of this wholesale onslaught of polluted air was a considerably higher death rate than usual, as reflected by the heavy toll taken in 1948 in Donora, a small American city, in 1952 in London with 4,000 deaths, in the industrial section of the Belgian Maas Valley, in the German Ruhr district and in Los Angeles. Just recently a windstill weather inversion created similar conditions concomitantly in London, Los Angeles, Rotterdam and Tokyo.

Damage is caused by the toxic carbon monoxide in automobile exhausts and sulfur dioxide, which is belched into the air by house chimneys and the smoke-stacks of oil refineries and other industries in such quantities that toxic nitrogen gases develop.

We can stop taxing the air we breathe by using petrol with a low sulfur content, gas cleaning by means of electrostatic precipitators and developing automobiles that do not pollute the air. A possibility lies in electricity-powered cars.

We have many ways and means to counter air pollution. Developing and implementing these measures will undoubtedly cost much money; but for the sake of our health we are left no other choice if we wish to stave off the specter of having to walk about with a gas mask.

Although several countries have pollution control programs with definite deadlines for implementation, the leading industrial concerns and especially the automobile industry do not seem all that intent on accelerating the pace of introducing improvements.

\section{Emissions}

Article 24 of the Swiss Federal Constitution, which is now being elaborated, provides protection against emissions such as air pollutants and noise. 
Already Schopenhauer described noise as the most irksome kind of disturbance. Everyone experiences noise nuisance in his home, on the street, at his place of work and during leisure hours. This constant source of harrassment can be conducive to ill health, insomnia, irritability and can even cause permanent damage to the nervous system.

People should therefore be spared this plague as far as possible through noise abatement campaigns, the improvement of sound-proofing norms, and the development of noiseless machines. At present a Swiss citizens' committee is fighting to obtain legislation forbidding supersonic aircraft from exceeding the speed of sound over inhabited areas.

\section{Toxic chemicals}

Much has lately been said and written about the detrimental effects of pesticides, herbicides, fungicides, DDT and other chemicals that find their way into our water and air. They are stored in the soil for years, accumulating there and later getting into the food chain of both man and animals.

Although man is loath to renounce the improvements these chemicals brought about in the yield and quality of agricultural produce, he must be far more careful in their application since too little is known about their effects. The testing and selection of chemicals falls within the purview of environmental pollution control.

\section{Radioactivity and atomic power stations}

Water has, since the beginning of history, been a source of energy; in fact, one of the oldest records of civilization is a legal code distributing water rights to power water-wheels and mills. The water reservoirs and various types of high and lowpressure hydraulic power plants developed later were even more effective.

The peaceful use of atomic energy represents a new preoccupation. Since the discovery of x-rays and radioactivity last century, after which radiologists suffered serious physical damage, and since the influence on the genetic structure of man, animal and plants was proved, science, medicine and technology were able to profit by these experiences, thus preparing the way for rapid progress. A number of reactors have already been built for research purposes; high capacity power stations, of which Beznau I is operational and others are being completed, convert nuclear energy into heat energy.

We have every reason to use the greatest care in examining whether the use of radioactive, fissionable material is dangerous for man or animals in any way. I feel that for our times at least this question can be answered to the negative, for there is no other branch of technology in which construction and operation are so safe and reliable, with such stringent regulations and checks, as that of reactors and atomic power plants.

Of course, all atomic installations must be closely surveyed and the norms concerning radiation doses admissible for man and his environment adjusted to new findings. 


\section{Thermal pollution of surface water}

Since only one third of the heat produced by a power station can be used to generate electricity, discharging the heated cooling waters into our rivers may seem the simplest and cheapest way of destroying this energy. But since this affects the ecological balance of the receiving body, provisional regulations, based on hydrobiological reasons, were drafted and will be adjusted to the results of the chemical, biological and ecological examinations being carried out in the Aare and Rhine Rivers. If the admissible temperature increase has already been reached or if the higher temperatures have adverse effects, one can still resort to cooling towers. Moreover other solutions for a more effective and economical use of thermal waters from nuclear power stations may soon be found.

Among the various sources of energy available to man only water remains quantitatively constant while the deposits of fossilized fuels such as coal, oil and natural gas will some day be exhausted. One must thus consider whether it would not be wiser to hedge our supplies of fossilized fuel, which took thousands of years to form and are irreplaceable. In view of his stupendous energy consumption man cannot wait for the formation of new deposits of coal and oil. Fossilized fuels should be reserved for better purposes especially for chemistry.

But then, our sources of nuclear energy are also being depleted - in fact much faster than we would care to see -- because uranium is available only in limited quantities.

The closed-circuit, helium-powered gas turbines developed by J. Ackeret and C. Keller offer an effective solution to the use of thermal waters from nuclear power plants. Long-distance heating systems or heat production and supply for industry and desalination plants will bring us one step closer to the complete utilization of the heat generated.

\section{Atomic bomb}

Although nuclear power stations and atomic bombs should not be brought into correlation with each other, the threat posed by the atomic bomb cannot be omitted in a discussion on survival.

Radioactive fallout was a source of grave concern towards the end of the $1950 \mathrm{~s}$ when considerable concentrations were found in the air, rain, water and even the human body. Thanks to the ban on bomb tests on the surface of the earth, however, this problem has practically been completely obviated.

The danger of the atom bomb nevertheless looms over mankind as a constant threat. We know only too well that the nuclear arsenals in the East and the West could destroy all life on Earth within the shortest time.

And this, gentlemen, is the product of man's intelligence, his ingenuity and organizational talent. Is one not reminded of Mephistopheles's scorn:

'A little better would he live, hadst Thou

Not given him a glimpse of heaven's light,

Which he calls reason and employs it only,

To live more beastlily than any beast.' 


\section{Reason, justice, conscience}

Harsh as this judgment on man may seem, it is, as regrettable as it might sound, to a large extent true. Man has created highly-developed civilizations, erecting impressive scientific as well as artistic monuments, but has he really raised himself, as the sole creature of the animal kingdom with a higher intelligence, over animals?

The din of war was heard throughout the entire history of man, but the situation has never been as precarious as in our times. Man has heinous crimes on his conscience: slave-trading, injustices that are now turning against him, unimaginable cruelties during the religious wars, unbridled class hatred and racism, and we have no guarantee that the list will not grow. Obviously, reason is not enough to guide man in his activities.

Reason must be coupled with man's more sublime instinct: his conscience. When conscience prevails over reason man then has the necessary wisdom to make living together in peace and harmony possible.

The sense of justice is intrinsic to all men. When 35 years ago I spent some time on a remote island of the Malay Archipelago, untouched by Western civilization, I was shown how this people, so close to nature, had a very fine feeling for justice. Rarely in my life had I ever felt as safe as then, working with natives who carried their bows and arrows about at all times.

The problems that must be solved to save mankind are so great that we must muster all our strength to tackle them. Until now man has oriented his ventures and undertakings according to economic, political and strategic motivations without asking himself whether his intentions were justifiable or meaningful.

All too often man has let himself be led by his thirst for conquest and military as well as economic subjugation and his yearning for success and fame. If we wish to survive we must place concepts such as fame and immortality in another context and perhaps take to heart a quotation from Heinrich Pestalozzi, who said: 'One can do far more by planting a single seed than any general in a military campaign.'

\section{Environmental pollution control}

It cannot be denied that stupendous feats must still be accomplished to improve our environment. Our lakes, oceans and coastal regions must be made clean; settlements, industry and agriculture must be supplied with service and drinking water and the level of toxic substances in the air and soil must be reduced.

Will man shirk from this task or will he grapple with it? Can mankind survive? I, personally, have faith in man's ingenuity and efficiency and am confident that he can make his environment liveable. To this end, however, the coordination of all forces available and the well-planned collaboration of all nations are indispensable.

\section{Overpopulation and the food problem}

It took man approximately 600,000 years to reach a population of $3 \frac{1}{2}$ billion; yet already 30 years from now this figure will have doubled, for each year there are 90 million mouths more to feed. This represents an increase of 2 percent. Thus the 
space available to each person is shrinking rapidly. Since during the centuries fertile land was changed into aride regions and even deserts, owing to man's mismanagement, the food situation is becoming more and more precarious each year.

But the population density and food is distributed very unevenly in the world. While we, in industrialized countries, gorge ourselves, two-thirds of the world is undernourished and 120,000 people starve to death each day, i.e. over 40 million each year. Three-quarters of all colored children, i.e. 22 percent of the children in the world, must go to bed hungry. A protein-deficient diet impedes the intellectual as well as physical development of a child and reduces its resistance against disease.

Everyone agrees that the problem of nutrition must be solved very soon. If it is not overcome in time, we can expect serious sociological repercussions.

In view of these facts, the nutrition problem seems so much more complex and almost insuperable when compared with that of environmental pollution control.

Only one-tenth of the surface of the earth is arable; millions of square miles of land cannot be used for food production due to erosion or unfavorable climatic conditions.

Yet if we make full use of our resources, there are still ways of avoiding world famine. A possibility lies in overcoming the deeply-rooted religious and traditional obstacles and taboos.

The United Nations' specialized agency, the Food and Agriculture Organization, is mobilizing all forces to solve the nutrition problem. Forecasts about whether the problem is really as serious are contradictory. Some feel that a world famine is inevitable, but others consider this hysterical as is reflected by this headline that appeared in the press: 'A World Famine Will Not Take Place.' One does not have to be very perspicacious to realize the catastrophic consequences such a newspaper article may have for an ambitious food program.

On the one hand, it is true that food production has been improved considerably and can be accelerated even more. Agriculture has enhanced the quality and quantity of its yields and made crops more resistant to insects.

Hundreds of thousands of square miles of land still lie fallow or are not used effectively.

To develop aride regions, however, takes time. Irrigation systems cannot be set up overnight. Know-how, machines, fertilizers and capital are the prerequisites for such a program which, in turn, are based on a higher standard of living of the population. The path is long and winding and, if fate wants it, entire peoples might starve to death before the potential crop-producing countries find the right way. Merely granting financial aid is senseless; the necessary infrastructure must be set up step by step.

\section{Family planning is indispensable}

The problem of world famine can be traced to the fact that the rate of growth of the population is far greater than that of food production.

This had already preoccupied T.R. Malthus 200 years ago and had prompted him to speak out in favor of very definite birth control measures. The world has unanimously come to the conclusion that only in this way could the problem of food dearth be solved. Programs have already been initiated and, according to statistics, 
modest results have been compassed on the regional level. But one swallow does not make a summer. In time we must check the rapid proliferation of the human race. To this end, a world-wide interdisciplinary approach is of the utmost importance.

\section{Better utilization of the oceans}

The resources of the oceans will also contribute to an improvement in food supplies. The chemicals dissolved in the water and the sunlight which filters through 100 meters of watcr enable the proliferation of plankton, which feeds the world of teeming microorganisms in the seas and is indirectly eaten by fish and crustaceans, which had always been a mainstay in man's diet. By steering production in fishery grounds by stimulating primary production, and by improving storage and transportation facilities for fish, man will obtain more profit from the yield of the oceans.

More intensive use of the ocean, however, presupposes that we redouble our efforts to keep it clean, a necessity that had already been emphatically pointed out above.

While the world follows news about oil catastrophes and their dire consequences for coastal regions with much apprehension, seafarers and researchers report that the ocean floor and seas of practically the entire globe are sorely contaminated with materials detrimental to life and that toxic substances are being found in the bodies of sea animals even in the far North. This might well make them unsafe for human consumption.

\section{Filling the protein gap}

A particularly acute danger for human nutrition lies in the lack of sufficient proteins, a mixture of 20 different types of amino acids linked together in various quantities. There are animal and vegetal proteins, but by far the best combination of amino acids is found in milk.

According to Prof. H. Aebi, Berne (1970), approximately 25 million tons of both animal and vegetal proteins are produced each year. However, the annual demand is as high as 60 million tons so that the protein deficit in the world corresponds to 10 million tons. Thus a way must be found to offset this deficiency. The following possibilities warrant consideration:

1. Intensification of efforts to improve methods of protein production and cattle raising to bring yield into harmony with need.

2. Quality improvement of conventional foods by supplying the missing amino acids through synthesized additives such as Lysine.

3. The extraction of protein from oil and petroleum products that are formed by microorganisms (bacteria and yeast). This process has already been started and will cover most of the protein deficit. One kilogram petroleum has already been converted into one kilogram dry yeast with a $40 \%$ protein content.

4. The synthesis of amino acids from gas and electricity, as was demonstrated in 1953 by St. L. Miller in Chicago, also gives us new hope. This electrochemical synthesizing process promises to provide us with protein structures which can be used as an effective weapon in the fight against hunger. 


\section{Which way is mankind drifting?}

Scientists have already set up a timetable for the eradication of man. Must we await the same fate as the innumerable species in the animal and plant kingdoms that spread and then became extinct to be remembered only through their fossils?

Man has one asset, namely that he can determine his own living conditions. But we have seen what a pass we have come to, and at the Environmental Pollution Control Symposium held in Zurich last November experts showed that the human body could, to a certain degree, become accustomed to pollutants in the water and air, objectionable odors, noise and toxic substances. A slow deterioration of the environment can be fateful in as far as man will be tempted to put off bringing his house in order until conditions deteriorate to such a degree that man, not being used to so much dirt, would die as Louis Pasteur's experiments with birds showed very demonstratively.

However, our main concern is not merely staying alive, but making our lives worth living and our environment more liveable.

At the Symposium on Environmental Pollution Control held at the Swiss Federal Institute of Technology it was emphasized that it was due to man's greed, his irrationality and unrestrained thirst for blood that rare species of plants and animals were completely wiped out. For us, this means the irreparable impoverishment of our lives, a development that is being fought against through International Conservation Year.

How can mankind be saved?

As we saw, our reason is not enough to keep us from slithering down the dangerous path we have borrowed; we must appeal to man's intellect to bring him back to his senses and to channel his almost unlimited faculties to make him more productive and the lives of all men richer.

However, to achieve this there must be a radical revision of values, a complete about-face, a powerful and concentrated endeavor on the part of all those conscious of their responsibilities. The roots for such an intellectual revolution must be solidly anchored in our ethics. The basis lies in mutual respect and confidence, but confidence is only possible among men of good will.

We, today, are further removed from this aim than ever. Each nation fears the other and feels that it can assert itself by entrenching itself behind an impressive military arsenal. For man, the decisive question now is:

'What can the willingness to find a better and more stable peace bring us?'

In all my endeavors to answer this difficult question, I was always confirmed in my conviction that there was only one way to achieve this goal, that is, to abide uncompromisingly by the commandment 'Love thy neighbor as thyself'. Only this attitude can lift us above the animal kingdom where only the fittest survives.

The task of the citizen and of today's youth is defined. We must orient all our endeavors towards this aim that concerns mankind in its entity. It is up to us to arm to do battle in this intellectual and spiritual revolution.

We have known the commandment of brotherly love for the past 2000 years; the threat of a nuclear cataclysm and the escalation of the arms race, however, show 
that we have not taken it seriously enough. It was obviously only the fear of total annihilation that has preserved us from the final catastrophe.

Has Christianity failed? Certainly not! But Christendom has. It is therefore high time to find a way of breaking the vicious circle of mutual mistrust and its dire consequences.

Through science, research, organization and planning we will be able to find a solution to environmental as well as world nutrition problems. The task is herculean; mental and spiritual forces must be mobilized and great financial sacrifices made. At the same time we must see to it that confidence and peace reigns on Earth.

But do we still have time? This depends on us. In order to escape the impending catastrophe, we must first recognize the danger and then concentrate all our wisdom, strength and courage on the necessary measures.

Twice during this century an impetus was given to bring human relations into harmony. The first attempt was made after World War I by President Woodrow Wilson who campaigned for the League of Nations, which unfortunately failed, and the second after World War II with the United Nations. The accomplishments of this organization are certainly far from encouraging but it is nevertheless continuing in its activities and some programs have even borne fruit. Thus we may hope that the world will give the United Nations more support, for it is, doubtless, the most appropriate organ to lead us out of the present impasse and to inspire us with the ultimate goal: peace and prosperity.

A Russian proverb says: 'Move quickly and you will overtake misfortune; move slowly and misfortune will overtake you.'

Reprint from the Swiss Journal of Hydrology 33, Fasc. 1 (1971) published with the support of the Stiftung der Wirtschaft zur Forderung des Gewässerschutzes in der Schweiz. 